Ankara University Journal of Faculty of Educational Sciences

Year: 2021, Volume: 54, Issue: 2, 627-644

DOI: 10.30964/auebfd.809552, E-ISSN: 2458-8342, P-ISSN: 1301-3718

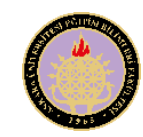

\title{
Power Relations and Exercise in Educational
} Institutions

\begin{tabular}{cccc}
\hline ARTICLE TYPE & Received Date & Accepted Date & Published Date \\
Review Article & 10.12 .2020 & 04.22 .2021 & 05.01 .2021 \\
\hline
\end{tabular}

Viliem Kurtulaj

Eötvös Loránd University

\begin{abstract}
The exercise of power can be noticed in any social or institutional relationship. In educational institutions, especially in the pre-university ones, power exercise can have a greater impact as students are not yet fully developed personalities or full subjects. This theoretical research is mainly based on a Foucauldian approach in terms of exploring and analyzing power relations in pre-university educational institutions. A deeper understanding of power exercise effects in schools might give school leaders, teachers and students the opportunity and the means to handle and control power relations during the educational process. At educational institutions, power is exercised by all actors, but in different proportions and dimensions. Power exercise can be controlled if the actors are aware of the power they exercise and the power that is exercised on them. The paper argues that, since the power exercise cannot be avoided and the authority in classroom remains the same, one of the ways in which power exercise can be controlled is through the teaching methods. It shows that the most appropriate form of teaching is the one that does not try to conceal or hide the exercise of power through changing the techniques of teaching.
\end{abstract}

Keywords: Education, pedagogy, power relations, school, Michel Foucault.

Ethics Committee Decision: This study does not include human subjects, thus ethics committee approval decision is not needed.

${ }^{1}$ Corresponding Author: PhD Candidate, Faculty of Education and Psychology, Doctoral School of Education, e-mail: viliemkurtulaj@gmail.com, https://orcid.org/0000-0001-7011-8475 
When discourse gets institutionalized in society, it tends to produce truths for the whole society and each truth is accompanied by power. As communication and discourse take place in the educational process, a kind of power is exercised, because power may be produced anywhere, at any time, at any point within each relation (Foucault, 2011). An educational institution, such as the school, is supposed to be a place and space where knowledge is learned and produced, and the students' talents, interests, and tendencies are discovered and developed. In order to be such, the educational institution should be a place of freedom where power exercises cannot impose limitations and restrictions on the actors involved (students or teachers). Therefore, it is important to understand how the power relations influence the knowledge creation and transmission process, as well as the actors in educational institutions. Using Foucault's $(1980 ; 2009 ; 2011)$ approach to the exercise of power, the aim of this paper is to analyse the power relations in pre-university educational institutions in order to understand how the exercise of power affects the educational process and quality. The terms pupil and student will be used here to refer to children and adolescents studying at primary and secondary schools respectively. Preschool education institutions and pupils, and higher education institutions and students, however, are not taken into account. Pupils in preschool institutions are not analysed here because they, as a result of their very young age, are educated in a more informal way, including entertainment such as games, playgrounds, etc. University students are not part of this study either, as they are over 18 years old and in most democratic countries are legally considered responsible subjects. In view of the above, the study attempts to answer the following research questions:

1. How do power relations influence the quality of pre-university education?

2. How can the effects of power exercise in the classroom be controlled?

This theoretical research paper intends to answer the above research questions by revealing and analysing power relations and the exercise of power in the classroom in two different approaches to pedagogy, namely manipulative pedagogy and communicative pedagogy, and the two main forms of teaching, the so called noninteractive approach, known widely as lecture, and the interactive approach, known as seminar.

The article pursues a philosophical approach. The main concepts that operate on the plane of immanence of this study are education and power. Therefore, this research deals and works with the meanings and implications of these two concepts, critically analysing the literature on the topic, and especially Michel Foucault's (1971, 1982) works, which deal with the concept of power and its application in education. However, other approaches, related to education and the exercise of power by authors such as Biesta (1998), Deacon (2006), Young (1990) or Freire (1982), are also dealt with to offer new insights into the field of philosophy of education.

In addition to the aforementioned authors, of course, there have been other researchers who have also worked on this topic from different perspectives. One of 
them is Michael W. Apple. According to him, within and outside the school, there are significant conflicts over knowledge and power relations. The educational process at school cannot be considered value-free but part of the world of experience. Apple claims that there is no one textual authority, nor one definitive set of facts that is divorced from its context of power relations. Schools are an integral part of a complicated and intertwined system that provides legitimacy to social groups and allows for the re-creation, maintenance, and ongoing construction of social and cultural ideologies (Apple, 1986). The pedagogical process inevitably contains power relations. In school, power is exercised by each participant and by the knowledge itself that circulates and disseminates there. Apple sees education as interconnected with at least three elements: culture, government and economy. Consequently, the educational process takes place in an environment where power exercise is present. Regardless of the way of teaching, it is important that the teacher does not conceive of the student as an object because, as Apple says, if a teacher treats a student as "really dumb", s/he might become "really dumb". Moreover, he thinks that the learning process in the classroom is also influenced by other extra-classroom power relations related to social structure, such as symbolic context and material circumstances. In the classroom, pedagogy should recognize the different social positions and cultural repertoires, and the power relations between them. As a result, Apple suggests that the methods of communication and the forms of control in the classroom have to be seen as a dialectical relationship between ideology and material and economic environment (Apple, 2013).

In their book Reproduction in Education, Society and Culture (1990), Bourdieu and Passeron conclude that authority originating from school-based knowledge was not only highly subjective but also reflective of a major power or cultural authority at work. Another researcher, Paul Willis, conceived of pedagogy at school as an instrument that plays an often-mystified role in the articulations of instrumentalism and expressivism. In his view, remaining educational autonomies, as well as their hopes for inclusion in emancipatory practices and initiatives, has to be fashioned on the grounds of relations of production and relations of consumption (Willis, 1999). Dissemination and acquisition of knowledge in school is not a linear, neutral, technical, or mechanical process. On the contrary, it is much more complex and it obtains power as well. Fiske (1989, p. 149) stated that "Knowledge is never neutral, it never exists in an empiricist, objective relationship to the real. Knowledge is power, and the circulation of knowledge is part of the social distribution of power." Regarding knowledge disseminated in school, Apple (1990) considered as naive to think of the school curriculum as neutral knowledge.

\section{Theoretical Framework}

I do not know whether I completely agree with Foucault (2009, pp. 96-97) that any discourse produces truths and consequently produces power, but I do agree that discourses produce power. One can say that power is mainly produced by force rather than by discourses. Actually, the concept of power has been treated by many authors 
in different fields of social sciences, and each of them has given this term specific features. In this paper, I use the concept of power as defined by Foucault:

The characteristic feature of power is that some men can more or less entirely determine other men's conduct - but never exhaustively or coercively. A man who is chained and beaten is subject to force being exerted over him, not power (Foucault, 2002, p. 324).

Power here is not conceived as something exclusive that belongs entirely to someone and not at all to someone else. Power cannot be treated as an object which can be given, exchanged or recovered but as an action that can be exercised. Power is never centralized only in one place or in one individual's possession. Certain bodies, gestures, discourses, and desires are some of the prime effects of power which can identify and constitute individuals. A person is both an effect of power and an element of power's articulation. So power constitutes the individual, but at the same time, it is the individuals who give shape to power. The individual is a vehicle of power as an exerciser, conveyor, and resultant (Foucault, 1980).

Since education is one of the many forms of social interactions, pedagogy is an area where discourses take place and play an important role. According to Biesta (1998), in his paper entitled "Pedagogy Without Humanism: Foucault and the Subject of Education", there are two main concepts of education: A) education as manipulation; and b) education as communication. If we make a distinction in eras, manipulative pedagogy is mostly related to the modern era, whilst communicative pedagogy is mostly related to the postmodern era. Referring the first concept (manipulative pedagogy), teacher and student enter into communication in the classroom as unequal. On the other hand, there is communicative pedagogy, which is related to postmodernism. The latter does not see education as merely instrumental relation. According to communicative pedagogy, education, as an instrumental relation, ignores the emerging personhood of the pupil/student. In communicative pedagogy, teacher and student are considered equal in the teaching-learning process at the school. From a narrow perspective, one can say that if manipulative pedagogy is applied, the impact of the power exercise is strong because the teacher directly exercises power on the pupil/student; whereas if communicative pedagogy is applied, the impact of the power exercise is weaker because both sides (teacher - pupil/student) exercise power in an interactive process and consequently oppose each other impact. In the classroom, the discourse which gets institutionalized is, most probably, the discourse of the teacher because $\mathrm{s} / \mathrm{he}$ is the authority. So, the teacher's discourse produces truths for the pupils/students. As a result, it is the teacher who exercises power on the students. Nevertheless, this is only half the picture. Referring to Foucault (2011), the exercising of power is not that simple and does not work exactly that way. He states that power is found everywhere because power may be produced at any time, at any point within each relationship. Power relations can be seen as a net, where points from where power is exercised can be anywhere, and points over whom power is exercised can also be anywhere. Power is everywhere... because it comes from 
anywhere (Foucault, 2011, p. 123). Consequently, the claim to eradicate the exercise of power in the classroom by changing teaching techniques seems impossible. In any situation, the persons involved will continue to exercise power over each other, in different proportions, even without their knowledge or intent.

\section{Manipulative Pedagogy vs. Communicative Pedagogy}

In manipulative pedagogy, the teacher and the student are unequal in the communication process in the classroom because the teacher is adult and consequently is considered subject, whereas the same thing cannot be said for the pupil/student because s/he is underage and in an ongoing formal learning process. The pupil/student is considered as a potential subject or subject to be. So, the relation teacher pupil/student here is asymmetric. The pupil/student is still in the process of becoming subject, influenced by the (manipulative) pedagogical process.

As I mentioned in the previous parts, modernism is associated with the manipulative form of pedagogy, while later, postmodernism brought changes into the form of pedagogy by shifting from the manipulative method to the communicative method, claiming that in the new pedagogical form, the manipulation of students by teachers has to be avoided (Biesta, 1998). On the other hand, manipulative pedagogy does not try to deny student manipulation by the teacher. On the contrary, it has its own arguments for why the teacher should manipulate the pupils and students, instead of pursuing symmetrical communication between equals in the classroom (Peters, 1963; Young, 1990; Gössling, 1993).

Manipulative pedagogy stands behind the idea that education in schools has to be asymmetrical because the relation between the teacher and the learners is a relation between two non-equal subjects, or to say it clearly, between someone who already is a subject (the teacher) and others who yet have to become subjects (the learners) (Biesta, 1998). So, the teacher has a mission to complete. S/he has to work on a process of teaching and the subject-formation of the students. In this respect, the concept of Freire (2005, p. 65) known as critical pedagogy or liberatory pedagogy could help us. Freire goes further by stating that critical/liberatory pedagogy helps both the teacher and the students to become subjects by developing consciousness. He considers consciousness as a condition for a human to become a subject (Freire, 1982). The teacher, who is an adult, and educated and trained to be such, is normally conscious of the contexts and the consequences of her/his actions. Consequently, the teacher is a subject. Meanwhile, the same cannot be said for the students under 18 years of age. As far as education is a teaching-learning process between subject and yet non-subjects, it is the duty of the teacher to manipulate pupils/students in order to help them in the process of subject-formation. The first step in helping the students become subjects is to make them aware and conscious that they are not yet full subjects, therefore, in this phase, they need to be taught/manipulated by a professional and specialized subject such as the teacher. 
Manipulative pedagogy sees the student identity as an outcome of pedagogical influence. It considers subjectivity an effect of pedagogical impact. "This shows that the modern (manipulative) pedagogical project is founded upon a normative presupposition, namely, the irreducible value of the (emerging) subjectivity of the child." (Biesta, 1998, p. 3). Especially, pupils are not yet capable or prepared of real dialogue and communication. "The pupil is thought to lack communicative competency... in a strict sense in which communicative competency is thought to consist of the social capacity for entering into argumentation and the cognitive capacity to generate or criticize arguments." (Young, 1990, pp. 111-115). Children can and must enter the "Palace of Communication" through the "Courtyard of Manipulation" (Peters, 1963, p. 55). So, education is seen as a trajectory where manipulation eventually develops into communication during the time.

Another factor, which can be used as an argument in favour of manipulative pedagogy is age. Each person - including the pupils and students - is not considered a full subject until a certain age. Communicative pedagogy states that education has to be a communication process between subjects (Biesta, 1998, pp. 3-5). From here, one might raise the question: At what age is a person or student considered a full or real subject (subject with full responsibility)? For example, the vast majority of countries in the world do not consider the people under the age of 18 (usually) as full subjects, therefore their parents or legal guardians are responsible for them and the consequences of their actions. Being under the age of 18, they lack many rights, including the right to vote, which is one of the fundamental human rights in the democratic world. The lack of these rights for people under the age of 18 is widely regarded as fair because full rights are for full subjects. A person, under the age of 18 , is an incomplete subject, therefore, s/he enjoys incomplete rights. One of these rights that is denied can be their right to communicative pedagogy. If pedagogy takes this criterion to consider the student as a subject or not - a criterion legitimized by almost all countries regarding several rights - then manipulative pedagogy becomes inevitable, and communicative pedagogy becomes ineffective, since communication - especially in the official institutions - is considered a process that occurs between subjects. As a result, the student in the school has to be manipulated by the teacher for her/his own good as long as s/he is not yet a complete subject.

On the other hand, communicative pedagogy, as can be understood, stands behind the idea of the need for free and noncoercive communication in the classroom. As closely related to the postmodernist concepts, this pedagogical theory deconstructs the modernist idea of the human subject as autonomous, independent, rational or presocial. Human being here is considered as produced by a number of factors and discursive practices. From a Foucauldian perspective, school education is considered a process of intersubjective relations; therefore, it is not a deep or profound truth about human subjectivity. The individual (teacher or student) is a product of several power relations. A relation between the pupils/students and the teacher is created through intercommunication. This relation should be equal and symmetrical. Unlike manipulative pedagogy, which states that education is a manipulation trajectory that 
can be developed into communication, communicative pedagogy states that the educational process should always be a communicative trajectory (Biesta, 1998).

Nevertheless, although the students are not yet full subjects, some sort of dialogue in the classroom can be helpful to them. This does not mean that students are equal to the teacher during the teaching process in the classroom. We would be naive to believe it. Nor does it mean that students should be an equal part of a communication process in the classroom because, like the teacher, they have to teach as well, but they should be allowed to express themselves. The classroom dialogue should also serve to give students the opportunity to learn how to articulate. Freire (1992) also supports the idea of dialogue in the classroom by stating the following:

Dialogue between teachers and students does not place them on the same footing professionally ... Teachers and students are not identical ... After all, it is a difference between them that makes them precisely students or teachers. Were they simply identical, each could be the other. Dialogue is meaningful precisely because the dialogical subjects, the agents in the dialogue, not only retain their identity, but actively defend it, and thus grow together. Precisely on this account, dialogue does not level them, does not 'even them out,' reduce them to each other. (Freire, 1992, p. 101).

Even though communication is a necessary element in education for Freire, he sees it as a dialog that does not mean equality in the relationship between the teacher and the students. The teacher remains the authority in the teaching-learning process. In the classroom, the teacher is still the authority, but s/he should not be authoritarian (Wayne, 2007).

\section{Power Exercise in the Classroom}

Based on the approaches of many scholars and philosophers, such as Foucault (1982), Biesta (1998), it can be stated that educational institutions are a kind of communication institution where power is exercised as well. Moreover, according to Foucault, "What distinguishes educational institutions from prisons, hospitals, and armies is that educational institutions emphasize more 'communication' rather than 'capacity' and 'power'." (Foucault, 1982, pp. 218-219). So, there is no doubt that communication is a very important element at schools. The power exercised during communication in the classroom is all-around and can come from all participating actors, of course in different proportions. It may very rarely happen that the exercise of power is one-sided.

In the school, those who are supposed to exercise power (the teachers) are caught up and subjected by the power relation, maybe as much as those over whom power is supposed to be exercised (the students). Not rarely, the teachers work under the invisible pressure of those over whom power is exercised. It is an undeniable fact that students also put pressure on teachers through communication and gestures. Teachers also can feel the pressure of the students even if the students do not speak at all, for 
example through their critical gazes or mimics, just as students often feel the pressure of teachers even when the latter do not speak (Deacon, 2006).

\section{Non-interactive (Lecture) vs. Interactive (Seminar)}

To understand what form of teaching exercises more power or less power, Foucault explores the two most prominent forms of teaching, the lecture (noninteractive pedagogy) and the seminar (interactive pedagogy) (Foucault, 1971, pp. 199-200). Apparently, the lecture is non-reciprocal, asymmetric and unequal in terms of communication and power relations. The seminar, on the other hand, tends to be more equal, symmetrical and reciprocal. At the seminar, the teacher exercises less power over the students because this form of teaching makes it possible for the power to come and be exercised to all more equally. On the other hand, at the lecture, the only speaker is the lecturer, so power through the discourse is exercised only in one direction, from the lecturer to the students. In fact, Foucault (1971) argues that the real power relations in the classroom are exercised differently.

According to Foucault, the lecture is more honest and less sly than the seminar in terms of the relations of power because it does not try to hide or camouflage the power that the teacher has and that is exercised in the classroom. To be clear, in both teaching methods there are inevitably power relations and exercise. The difference in power relations hides behind the claims of the two teaching methods.

A lecture which is tentative about its truth-claims and which exposes itself to criticism might neutralize power relations by rendering them more visible; whereas the ostensible freedom and reciprocity of the seminar may disguise power relations to the extent that students uncritically absorb what is only the informed opinion of the teacher. (Deacon, 2006, p. 184).

When the student attends a lecture, s/he is aware of the power exercised by the teacher/lecturer in the classroom or auditorium. In this way, being aware of it, the student is prepared to face the power exercised by the teacher. Consequently, being aware and prepared, s/he is less exposed to this exercise of power over her/him.

On the other hand, the students attend the seminar with the thought that there they will participate in a communication process where are all equal and free to speak, and consequently, no power is exercised over them. The seminar gives everyone the opportunity to speak and express themselves. On the practical side, seminar makes the teacher more equal with the students. In this way, the seminar claims that there is less power exercised, since the figure of power, that is the teacher, becomes part of the discussion with students. Thus, the students, seeing the form of the seminar where the teacher does not speak all the time, but converse with them, are unaware of the power exercised at the seminar and therefore are unprepared for it. Not being prepared for the power that can be exercised over them during the seminar, students are more exposed and vulnerable to the "hidden" power that may come from the teacher and their peers as well. At the seminar, the students are free to speak, but this is where the power is exercised over them. The student feels the pressure of the power exerted on 
her/him when s/he has to speak; when s/he has to be active in the classroom; or in other eventual situations that may arise during the interactive teaching process at the seminar.

Apart from the fact that being unaware and unprepared for the power exercise makes students more vulnerable to the power relations, there are two other reasons why at the seminar pressure and power exercise is not disappear or weakened, even though all are supposed to be equal and everyone has the right to speak or to express.

The second reason is that the power is not exercised by the teacher only. In relationships, power can come from anywhere and anyone can be subject to the exercise of power. Thus, at the seminar, power can be exercised by the teacher and by each student. Every student who speaks at the seminar exercises power over other students, even over the teacher. Moreover, because the students are supposed to speak and be active at the seminar, they feel the pressure to do it even when they may have nothing to say. It is the power of the teacher and the other students exercised over the student each time s/he makes the decision to speak or not at the seminar. The student is under the power of reactions not only of the teacher but also of the other students. So, there is no decrease in the level of power exercised in the classroom, but a diversification and maybe an increase of it. Perhaps there is a decrease in teacher dominance, but dominance is another concept that differs from power.

The third argument for the existence of the power exercise at the seminar is that the power of the teacher over the students is not lost, but it only gets camouflaged. The teacher's relation with the students at the seminar may be closer and friendlier than the relation of the teacher with the students at the lecture. That is actually true. However, the relation remains hierarchical and official during the teaching process at the educational institutions. This means that the statuses of the teacher and the students do not change. The status or nature of their relation does not change either. The relation can change the shape but the status of the participants in this relation remains the same. Consequently, neither the core nor the relation function changes. Even at the seminar, the teacher is the one who has the status of the person who teaches others even though the form of teaching may be different. Moreover, as long as the status of the participants at the seminar does not change, the teacher remains the authority who evaluates the students. So, the teacher, using grades and marks, still has the power to "punish" the students who do not perform well or to "reward" the good performing ones. The students are constantly under the pressure of the evaluation, so consequently they are somehow under the power of the one who evaluates them for what they say or do not say. So, it would be naive to claim that the teacher's power at the seminar is disappeared or even faded.

The arguments I presented above, concerning the power exercise in the classroom, which rely mainly on Foucault's $(1982,2009,2011)$ ideas and concepts regarding the exercise of power in society and in educational institutions in particular, show that changing the teaching technique from lecture to seminar does not reduce the exercise of power in the classroom. Hence the seminar can be more suitable to be 
used for training in methods, vocational and technical teaching than to encourage and develop free and critical thinking in the schools (Deacon, 2006, p. 184). On the other hand, the lecture, which gives the student more space and freedom to think without putting pressure on the necessity to speak often and quickly as at the seminar, seems more appropriate and more valuable to teach students theoretical subjects that require a deeper thought to be understood.

\section{Discussion, Conclusion and Suggestions}

In conclusion, it can be stated that at pre-university educational institutions, power is exercised by all actors, but in different proportions and dimensions. While the exercise of power is inevitable in any social relationship, in schools, in addition to social relationships, there is an institutional relation as well which increases and diversifies the exercise of power. This study aimed at revealing and obtaining a deeper understanding of the relations and exercise of power in the classrooms at preuniversity educational institutions.

Regarding the first research question I raised at the beginning of this article (How do power relations influence the quality of pre-university education?), it has been argued that power relations and exercise of power in schools can become an obstacle to the development of knowledge, creation and freedom of thought. This could happen because power relations in the classroom are all-around and can come from all participating actors, of course in different proportions. Not being aware and prepared for the power that can be exercised in the classroom, teachers and students are more exposed and vulnerable to the "hidden" power that may come from any individual. Regarding the second research question (How can the effects of power exercise in the classroom be controlled?), it has been alleged that the actors in schools have to be aware of the power they exercise and is exercised on them so that the exercise of power can be controlled and managed to a certain degree. The first step in controlling the effects of power exercise in the classroom is to make the teacher and students aware and conscious that each of them exercises power over the others and, at the same time, is subject to the exercise of power by the others, consciously or unconsciously. This could reduce the negative influence of power relations on the educational process, but, of course, could not completely avoid it. The claim to eradicate the exercise of power in the classroom by changing teaching techniques seems impossible and unrealistic.

Also, in this article, it has been claimed that the communication process, as if all participants were equal, requires all parties to be subjects. The manipulative way of teaching in the school classrooms is acceptable as long as the students are not full subjects (under the age of 18). This does not mean that communication in the classroom between the teacher and the students is not allowed. Communication should not pretend equality but should be more in the form of dialogue aiming at the development of the students' articulation and fostering the development of the students' talents, interests and tendencies. 
Inter-exercise of power in the classroom is inevitable regardless of whether there is inter-communication between the teacher and the students or not. The form of teaching (lecture or seminar) does not reduce the exercise of power in the classroom as long as the status of the actors does not change and, as long as power can be exercised by anyone. What can be changed, however, is the awareness of students and teachers about the power exercise in the classroom. Power becomes more controllable and manageable when all involved persons are aware of it.

Since the exercise of power is inevitable in the classroom, the most appropriate form of teaching is one that does not try to conceal the exercise of power through changing the techniques. Teaching techniques can be changed in order to:

- make the knowledge be acquired more accessible and penetrable to everyone;

- make the process more interesting and inclusive;

- urge the students to study and develop their talents.

Still, the change of techniques does not eliminate the exercise of power in education as long as power can be exercised in any situation by any actor.

While this article analysed the power relations in the classroom from a philosophical perspective, it did not deal with the alternative types of teaching other than lecture and seminar. Also, this paper is conceived according to the western worldview of subjectivity and education, not taking into account other cultures in the world and their relations with education and power. These are limitations of the study. However, these are also invitations for other education and philosophy of education scholars to analyse the alternative forms of teaching in different cultures in relation to the exercise of power. While most studies in this field deal with the exercise of power by educational institutions over students or society, or the power that the teacher exercises over students, this research deals with the micro level, bringing to attention the relationships and ways of power exercise by all actors in the classroom.

\section{Ethics Committee Decision}

This study does not include human subjects, thus ethics committee approval decision is not needed.

\section{References}

Apple, M. W. (1986). Teachers and Texts. New York: Routledge.

Apple, M. W. (1990). Ideology and Curriculum. New York: Routledge.

Apple, M. W. (2013). Knowledge, Power, and Education. New York and London: Routledge.

Biesta, J. J. G. (1998). Pedagogy Without Humanism: Foucault and the Subject of Education. Interchange, 29(1), 1-16. 
Bourdieu, P., and Passeron, J. C. (1990). Reproduction in Education, Society and Culture. London: SAGE Publications Ltd.

Deacon, R. (2006). Michel Foucault on Education: A Preliminary Theoretical Overview. South African Journal of Education, 26(2), 177-187.

Fiske, J. (1989). Reading the Popular. Boston: Unwin Hyman.

Foucault, M. (1971). J. K. Simon: A Conversation with Michel Foucault. Partisan Review, 38, 192-201.

Foucault, M. (1980). Power/Knowledge: Selected Interviews \& Other Writings 19721977. Edited by Colin Gordon. New York: Pantheon Books.

Foucault, M. (1982). The Subject and Power. Afterword to Dreyfus HL \& Rabinow P. Michel Foucault: Beyond Structuralism and Hermeneutics. Brighton: Harvester.

Foucault, M. (2002). Omnes et Singulatem. In J. D. Faubion (Ed.), Essential Works of Foucault 1954-1984, volume 3: Power (pp. 298-325). London: Penguin Books.

Foucault, M. (2009). Pushteti dhe Dija. Tirana: ISP \& Dita 2000.

Foucault, M. (2011). Historia e Seksualitetit 1. Tirana: UET Press.

Freire, P. (1982). Education as the Practice of Freedom (M. B. Ramos, Trans.). In Education for Critical Consciousness (pp. 1-84). New York: Continuum.

Freire, P. (2005). Pedagogy of the Oppressed. New York and London: Continuum.

Gössling, H. J. (1993). Subjekt Werden. Historisch-systematische Studien zu einer pädagogischen Paradoxie. Weinheim: Deutscher Studien Verlag.

Peters, R. S. (1963). Reason and Habit: The Paradox of Moral Education. In W. R. Niblett (Ed.), Moral Education in a Changing Society (pp. 46-65). London: Faber \& Faber Ltd.

Young, R. (1990). A Critical Theory of Education. Habermas and Our Children's Future. New York: Teacher's College Press.

Wayne, A. (2007). Epistemology of the Oppressed: The Dialectics of Paulo Freire's Theory of Knowledge. Journal for Critical Education Policy Studies, 5(2), 1-14

Willis, P. (1999). Critical Education in the New Information Age. Labor Power, Culture, and the Cultural Commodity. New York: Rowman \& Littlefield Publishers, Inc. 


\title{
Eğitim Kurumlarında İktidar İlişkileri ve Uygulanışı
}

\begin{tabular}{cccc}
\hline MAKALE TÜRÜ & Başvuru Tarihi & Kabul Tarihi & Yayım Tarihi \\
Derleme Makalesi & 12.10 .2020 & 22.04 .2021 & 01.06 .2021 \\
\hline
\end{tabular}

Viliem Kurtulaj

Eötvös Loránd Üniversitesi

\begin{abstract}
Öz
İktidar kullanımı, herhangi bir sosyal veya kurumsal ilişkide fark edilebilir. Eğitim kurumlarında, özellikle üniversite öncesi kurumlarda, iktidar uygulanışı, öğrenciler henüz tam olarak gelişmiş kişilikler veya tam denekler olmadığından daha büyük bir etkiye sahip olabilir. $\mathrm{Bu}$ kuramsal araştırma, esas olarak üniversite öncesi eğitim kurumlarında güç ilişkilerinin incelenmesi ve analiz edilmesi açısından Foucaultcu bir yaklaşıma dayanmaktadır. Eğitim kurumlarında, sınıfta/oditoryumda iktidar ilişkileri, yaratıcılık, yenilikçilik, bilgi üretimi, özümseme vb. için bir engel durumuna gelebilir; öğretmenlerin, öğrencilerin ve akademisyenlerin düşünce özgürlüğünü engelleyebilir. Okullarda iktidarın uygulanışının etkilerinin daha derin bir şekilde anlaşılması, okul yöneticilerine, öğretmenlere ve öğrencilere eğitim sürecinde bunları yönetme ve denetleme fırsatını ve araçlarını verebilir. Eğitim kurumlarında iktidar, tüm aktörler tarafindan ancak farklı oran ve boyutlarda kullanılır. İktidarın uygulanışı, aktörler uyguladıkları iktidarın ve üzerlerinde uygulanan iktidarın farkındaysa kontrol edilebilir. Bu makale, iktidarın uygulamasından kaçınılamayacağı ve sınıftaki otorite aynı kaldığı için, iktidar uygulamasının kontrol edilebileceği yollardan birinin öğretim yöntemleri aracılığıyla olduğunu savunmaktadır. En uygun öğretme biçiminin, öğretme tekniklerini değiştirerek iktidar uygulamasını saklamaya veya gizlemeye çalışmayan bir öğretim biçimi olduğunu gösterir.
\end{abstract}

Anahtar sözcükler: Eğitim, pedagoji, iktidar ilişkileri, okul, Michel Foucault.

Etik Kurul Kararı: Derleme makalesi olduğu için etik kurul kararı gerekmemektedir.

\footnotetext{
${ }^{1}$ Sorumlu Yazar: Doktora Adayı, Eğitim ve Psikoloji Fakültesi, Lisansüstü (Doktora) Eğitim Okulu, eposta: viliemkurtulaj@gmail.com, https://orcid.org/0000-0001-7011-8475
} 


\section{Amaç ve Önem}

Söylem, toplumda kurumsallaştığı zaman, tüm toplum için doğrular üretme eğilimindedir ve her gerçeğe iktidar eşlik eder. Eğitim sürecinde iletişim ve söylem yer aldıkça, bir tür iktidar uygulanılır, çünkü iktidar her ilişkide herhangi bir zamanda, herhangi bir noktada, herhangi bir yerde üretilebilir (Foucault, 2011). Okul gibi bir eğitim kurumunun, bilginin öğrenildiği ve üretildiği ve öğrencilerin yeteneklerinin, ilgi alanlarının ve eğilimlerinin keşfedildiği ve geliştirildiği bir yer ve alan olması gerekir. Böyle olabilmesi için eğitim kurumu, iktidar ilişkilerinin ilgili aktörlere (öğrenciler veya öğretmenler) sınırlama ve kısıtlamalar getiremeyeceği bir özgürlük yeri olmalıdır. Bu nedenle iktidar ilişkilerinin bilgi oluşturma ve aktarma sürecini ve eğitim kurumlarındaki aktörleri nasıl etkilediğini anlamak önemlidir. Foucault'nun $(1980 ; 2009 ; 2011)$ iktidar uygulaması yaklaşımı kapsamında bu makalenin amacı, iktidar uygulamasının eğitim sürecini ve niteliği (kaliteyi) nasıl etkilediğini anlamak için üniversite öncesi eğitim kurumlarındaki iktidar ilişkilerini çözümlemektir. Öğrenci (pupil, student) terimi burada sirasiyla ilkokul ve ortaokullarda okuyan çocukları ve gençleri belirtmek için kullanılmıştır. Okul öncesi eğitim kurumları ve yüksek öğretim kurumları bu makalede dikkate alınmamaktadır. Okul öncesi kurumlardaki öğrenciler de bu makalede analiz edilmemektedir çünkü çok kü̧̈ük yaşlarda olmalarının bir sonucu olarak, oyunlar ve oyun alanları gibi eğlenceler de dahil olmak üzere daha gayri resmi bir şekilde eğitilmektedirler. Üniversite öğrencileri de 18 yaşın üzerinde olduklarından ve çoğu demokratik ülkede yasal olarak sorumlu yetişkinler olarak kabul edildiğinden bu çalışmanın bir parçası değildirler. Yukarıdaki açıklamaların ışığında, bu makale aşağıdaki araştırma sorularını yanıtlamaya çalışmaktadır:

1. İktidar ilişkileri üniversite öncesi eğitimin niteliğini nasıl etkiler?

2. Sınıftaki iktidar kullanımının etkileri nasıl kontrol edilebilir?

\section{Yöntem}

$\mathrm{Bu}$ makale, pedagojiye iki farklı yaklaşımla (yani manipülatif pedagoji ve iletişimsel pedagoji) sınıfta iktidar ilişkilerini ve iktidar uygulanışını ortaya koyarak ve analiz ederek yukarıdaki araştırma sorularını yanıtlamayı amaçlamaktadır. Ayrıca yaygın olarak ders (lecture) olarak bilinen sözde etkileşimli olmayan yaklaşım ve seminer (seminar) olarak bilinen etkileşimli yaklaşım olmak üzere iki ana öğretim biçimi ile ilgilenir.

Bu kuramsal araştırma makalesi felsefi bir yaklaşım izlemektedir. Bu çalışmada içkinlik düzleminde işleyen ana kavramlar eğitim ve iktidardır. Bu nedenle bu araştırma, bu iki kavramın anlamlarını ve çıkarımlarını, konuyla ilgili alanyazını eleştirel bir şekilde analiz eder ve özellikle de iktidar kavramı ve eğitimdeki uygulamasıyla ilgilenen Michel Foucault'nun (1971, 1982) çalışmalarını ele alır. Bununla birlikte Biesta (1998), Deacon (2006), Young (1990) veya Freire (1982) gibi yazarların eğitim ve iktidar kullanımıyla ilgili diğer yaklaşımları da eğitim felsefesi alanına yeni anlayışlar sunmak için ele alınmaktadır. 


\section{Kuramsal Yaklaşım}

Bu makalenin yazarı Foucault'nun (2009, ss. 96-97) iddia ettiği gibi herhangi bir söylemin gerçek ürettiğine ve sonuç olarak iktidar ürettiğine tamamen katılıp katılmadığını bilmemekte ancak söylemlerin iktidar ürettiğine katılmaktadır. İktidarın söylemlerden çok zorla üretildiğini de iddia edilebilir. Aslında iktidar kavramı, sosyal bilimlerin farklı alanlarında birçok yazar tarafından ele alınmış ve her biri bu kavrama belirli özellikler vermiştir. Bu makalede, Foucault tarafından tanımlanan iktidar kavramı kullanılmıştır. Buna göre:

The characteristic feature of power is that some men can more or less entirely determine other men's conduct - but never exhaustively or coercively. A man who is chained and beaten is subject to force being exerted over him, not power. [İktidarın karakteristik özelliği, bazı insanların diğer insanların davranışlarını aşağı yukarı tamamen belirleyebilmesidir - ancak asla kapsamlı veya zorlayıcı bir şekilde. Zincirlenmiş ve dövülmüş bir insan, kendisine uygulanan zorlamaya tabidir, ancak iktidara değil.] (Foucault, 2002, s. 324).

Burada iktidar, bir başkasına değil, tümüyle birine ait olan özel bir şey olarak düşünülmemiştir. İktidar, verilebilecek, değiş tokuş edilebilecek veya geri alınabilecek bir nesne olarak ele alınamaz ancak uygulanabilecek bir eylem olarak ele alınmalıdır. İktidar hiçbir zaman tek bir yerde veya bir bireyin mülkiyetinde merkezileștirilmez. Belirli bedenler, jestler, söylemler ve arzular, bireyleri tanımlayabilen ve onlara sahip olabilen iktidarın temel etkilerinden biridir. Kişi hem gücün bir etkisi hem de iktidarın eklemlenmesinin bir öğesidir. Öyleyse iktidar bireyi oluşturur ama aynı zamanda iktidarı şekillendirenler de bireylerdir. Birey, bir uygulayıcı, taşıyıcı (konveyör) ve sonuç olarak bir iktidar aracıdır (Foucault, 1980).

Eğitim birçok sosyal etkileşim biçiminden biri olduğu için pedagoji, söylemlerin gerçekleştiği ve önemli bir rol oynadığı bir alandır. Biesta'ya (1998) göre, "Pedagogy Without Humanism: Foucault and the Subject of Education" başlıklı makalesinde, eğitimin iki ana yönü vardır: a. Manipülasyon olarak eğitim; b. İletişim olarak eğitim. Çağlarda bir ayrım yaparsak, manipülatif pedagoji çoğunlukla modern çağla ilişkiliyken iletişimsel pedagoji çoğunlukla postmodern dönemle ilgilidir. İlk kavramı (manipülatif pedagoji) referans alan öğretmen ve öğrenci, sınıfta eşitsiz olarak iletişime geçer. Öte yandan, postmodernizm ile ilgili iletişimsel pedagoji de vardır. $\mathrm{Bu}$ ikinci yaklaşım, eğitimi yalnızca araçsal bir ilişki olarak görmez. İletişimsel pedagojiye göre eğitim, araçsal bir ilişki olarak öğrencinin ortaya çıkan kişiliğini görmezden gelir. İletişimsel pedagojide öğretmen ve öğrenci okuldaki öğretmeöğrenme sürecinde eşit kabul edilir. Dar bir perspektiften, manipülatif pedagoji uygulanırsa, iktidar alıştırmasının etkisinin güçlü olduğunu çünkü öğretmenin doğrudan öğrenci üzerinde iktidar uyguladığını söyleyebilir; oysa iletişimsel pedagoji uygulanırsa, iktidar alıştırmasının etkisi daha zayıftır çünkü her iki taraf (öğretmen öğrenci) etkileşimli bir süreçte iktidar kullanır ve sonuç olarak birbirlerinin etkisine karşı çıkarlar. Sınıfta kurumsallaşan söylem büyük olasılıkla öğretmenin söylemidir 
çünkü otorite odur. Böylece öğretmenin söylemi öğrenciler için gerçekleri üretir. Sonuç olarak, öğrenciler üzerinde güç uygulayan öğretmendir. Yine de bu, resmin sadece yarısıdır. Foucault'ya (2011) atıfta bulunarak iktidarın kullanılması o kadar basit değildir ve tam olarak bu şekilde çalışmaz. İktidar ilişkileri, iktidarın uygulandığı noktaların herhangi bir yerde olabileceği ve üzerinde iktidarın uygulandığı noktaların da herhangi bir yerde olabileceği bir ağ olarak görülebilir. İktidar her yerdedir ... çünkü her yerden gelir (Foucault, 2011, s. 123). Dolayısıyla öğretim tekniklerini değiştirerek sınıftaki iktidar kullanımını ortadan kaldırma iddiası olanaksız görünmektedir. Her durumda bu sürece dahil olan kişiler, bilgileri veya niyetleri olmasa bile, farklı oranlarda birbirleri üzerinde iktidar kullanmaya devam edeceklerdir.

Foucault (1982) ve Biesta (1998) gibi birçok bilim insanı ve filozofun yaklaşımlarından hareketle eğitim kurumlarının iktidarın da kullanıldığı bir tür iletişim kurumu olduğu söylenebilir. Dahası Foucault'ya göre, "what distinguishes educational institutions from prisons, hospitals, and armies is that educational institutions emphasize more 'communication' rather than 'capacity' and 'power'". ["Eğitim kurumlarını hapishanelerden, hastanelerden ve ordulardan ayıran şey, eğitim kurumlarının 'kapasite' ve 'güç' yerine daha fazla 'iletişim'e vurgu yapmasıdır."] (Foucault, 1982, ss. 218-219). Dolayısıyla okullarda iletişimin çok önemli bir etken olduğuna kuşku yoktur. Sınıftaki iletişim sırasında uygulanan iktidar çok yönlüdür ve katılan tüm aktörlerden gelebilir, kuşkusuz farklı oranlarda. İktidar kullanımının tek taraflı olduğu çok nadiren görülebilir.

Okulda, iktidar kullanması beklenenler (öğretmenler), belki de üzerinde iktidarın kullanılması beklenenler (öğrenciler) kadar iktidar ilişkisine yakalanır ve maruz kalır. Çoğu zaman öğretmenler de üzerlerinde iktidar uygulayan kişilerin görünmez baskısı altında çalışırlar. Öğrencilerin de iletişim ve jestlerle öğretmenlere baskı yaptıkları yadsınamaz bir gerçektir. Öğretmenler, öğrenciler hiç konuşmasalar bile, örneğin eleştirel bakışları veya mimikleri yoluyla öğrencilerin baskısını hissedebilirler, tıpkı öğrenciler konuşmadığında bile öğretmenlerin baskısını hissettikleri gibi (Deacon, 2006).

\section{Bulgular}

Yukarıdaki bölümlerde sınıfta iktidar uygulamasına ilişkin sunulan, temelde Foucault'nun $(1982,2009,2011)$ toplumda ve özellikle eğitim kurumlarında iktidarın kullanımına ilişkin fikir ve kavramlarına yönelik dayanaklar, öğretme tekniğini dersten seminere doğru değiştirmenin sınıfta iktidar kullanımını azaltmadığını göstermektedir. $\mathrm{Bu}$ nedenle seminer, okullarda özgür ve eleştirel düşünmeyi özendirmek ve geliştirmek yerine, mesleki ve teknik öğretimde eğitim için kullanılmaya daha uygun olabilir (Deacon, 2006, s. 184). Öte yandan, öğrenciye seminerde olduğu gibi sık ve hızlı konuşma baskısı yapmadan daha fazla alan ve düşünme özgürlüğü veren ders, öğrencilere daha derin bir düşüncenin anlaşılması gereken kuramsal konuları öğretmek için daha uygun ve daha değerli görünmektedir. 


\section{Tartışma, Sonuç ve Öneriler}

Sonuç olarak, üniversite öncesi eğitim kurumlarında iktidarın tüm aktörler tarafından ancak farklı oran ve boyutlarda kullanıldığı söylenebilir. Her sosyal ilişkide iktidarın kullanılması kaçınılmaz olmakla birlikte okullarda, sosyal ilişkilere ek olarak, iktidar kullanımını artıran ve çeşitlendiren kurumsal bir ilişki de vardır. Bu makale, üniversite öncesi eğitim kurumlarında sınıflardaki iktidar ilişkileri ve uygulanışını daha derin bir şekilde ortaya koymayı ve çözümlemeyi amaçlamaktadır.

$\mathrm{Bu}$ makalenin başındaki ilk araştırma sorusuyla ilgili olarak (İktidar ilişkileri üniversite öncesi eğitimin kalitesini nasıl etkiler?), okullarda iktidar ilişkileri ve iktidarın kullanılmasının bilgi, yaratma ve düşünce özgürlüğünün gelişmesine engel olabileceği ileri sürülmüştür. Bu, sınıftaki iktidar ilişkilerinin çok yönlü olması ve tüm katılımcı aktörlerden, elbette farklı oranlarda gelebileceği için olabilir. Sınıfta kullanılabilecek iktidarın farkında ve hazırlıklı olmayan öğretmen ve öğrenciler, herhangi bir bireyden gelebilecek "gizli" güce karşı daha açık ve savunmasızdır. İkinci araştırma sorusuyla ilgili olarak (Sınıftaki iktidar kullanımının etkileri nasıl kontrol edilebilir?), okullardaki aktörlerin uyguladıkları iktidarın farkında olmaları gerektiği ve iktidar kullanımının belirli bir dereceye kadar kontrol edilebilmesi ve yönetilebilmesi için üzerlerinde uygulandığı iddia edilmiştir. Sınıfta iktidar uygulamanın etkilerini kontrol etmenin ilk adımı, öğretmen ve öğrencilerin her birinin diğerleri üzerinde iktidar uyguladığının ve aynı zamanda diğerlerinin iktidar uygulamasına tabi olduğunun farkına varmalarını sağlamaktır. Bu, iktidar ilişkilerinin eğitim süreci üzerindeki olumsuz etkisini azaltabilir ancak elbette bundan tamamen kaçınılamaz. Öğretim tekniklerini değiştirerek sınıfta iktidar uygulanışını ortadan kaldırma iddiası olanaksızdır ve gerçekçi görünmemektedir.

Ayrıca bu makalede tüm katılımcılar eşitmiş gibi iletişim sürecinin tüm taraflarının birer özne olmasını gerektirdiği ileri sürülmüştür. Okuldaki sınıflarda manipülatif öğretim şekli, öğrenciler tam özne olmadıkları sürece (18 yaşın altında) kabul edilebilir. Bu, sınıfta öğretmen ve öğrenciler arasında iletişime izin verilmediği anlamına gelmez. İletişim eşitlik iddiası taşımamalı, daha çok öğrencilerin eklemlenmesini geliştirmeyi ve öğrencilerin yeteneklerini, ilgi alanlarını ve eğilimlerini geliştirmeyi amaçlayan bir iletişim (diyalog) biçiminde olmalıdır.

Öğretmen ve öğrenciler arasında karşılıklı iletişim olup olmadığına bakılmaksızın, sınıfta karşılıklı iktidar uygulanması kaçınılmazdır. Aktörlerin statüsü değişmediği ve iktidar herkes tarafından kullanılabildiği sürece öğretim biçimi (ders veya seminer) sınıfta iktidar kullanımını azaltmaz. Bununla birlikte değiştirilebilecek şey, öğrencilerin ve öğretmenlerin sınıftaki iktidar uygulaması hakkındaki farkındalıklarıdır. İktidar, tüm aktörler bunun farkına vardığında daha kontrol edilebilir ve yönetilebilir bir duruma gelir.

Sınıfta iktidarın kullanılması kaçınılmaz olduğundan, en uygun öğretim şekli, teknikleri değiştirerek iktidar kullanımını gizlemeye çalışmamaktır. Öğretim teknikleri şu amaçlarla değiştirilebilir: 
. Bilginin herkes için daha erişilebilir ve anlaşılır olmasını sağlamak için;

. Süreci daha ilginç ve kapsayıcı bir duruma getirmek için;

. Öğrencileri yeteneklerini çalışmaya ve geliştirmeye özendirmek için.

Yine de iktidar, herhangi bir durumda herhangi bir aktör tarafindan kullanılabildiği sürece, tekniklerin değişimi eğitimde iktidarın kullanımını ortadan kaldırmaz.

Bu makale sınıftaki iktidar ilişkilerini felsefi bir bakış açısıyla çözümlerken ders ve seminer dışındaki alternatif öğretim türlerini ele almamıştır. Ayrıca bu kuramsal araştırma, dünyadaki diğer kültürler ve bunların eğitim ve iktidar ile ilişkileri dikkate alınmadan, Batı dünyasının öznellik ve eğitim görüşüne göre tasarlanmıştır. Bunlar çalışmanın sınırlılıklarıdır. Bununla birlikte bunlar, aynı zamanda diğer eğitim ve eğitim felsefesi akademisyenlerinin iktidarın kullanılmasıyla ilgili olarak farklı kültürlerdeki alternatif öğretim biçimlerini analiz etmeleri için davetiyelerdir. $\mathrm{Bu}$ alandaki çoğu çalışma, eğitim kurumlarının öğrenciler veya toplum üzerindeki iktidarını ya da öğretmenin öğrenciler üzerinde uyguladığı iktidarı ele alırken bu araştırma, konunun mikro düzeyle ilgilenir ve sinıftaki tüm aktörlerin iktidar uygulaması sürecindeki ilişkilerine ve araçlarına dikkat çeker.

\section{Etik Komite Kararı}

Derleme makalesi olduğu için etik kurul kararı gerekmemektedir. 